\title{
How does Environmental Regulation Effect Green Growth? An Empirical Investigation from China
}

\author{
Deshan $\mathrm{Li}^{1 *}$, Yanfen $\mathrm{Zhao}^{2}$ \\ ${ }^{1}$ College of Economics, Shanxi University of Finance and Economics, Taiyuan, China \\ ${ }^{2}$ College of Resources and Environment, Shanxi University of Finance and Economics, Taiyuan, China
}

Received: 16 March 2020

Accepted: 20 July 2020

\begin{abstract}
Based on panel data from 30 Chinese provincial administrations during 2001-2016, this study uses the Global Malmquist-Luenberger (GML) index to measure provincial green productivity and employs a spatial econometric model to examine the impact of environmental regulation on green productivity. The results indicate that China's overall green productivity has increased in trend during the research period, but there are significant regional differences, with those in the east showing greater increase than those in the mid-west. Beyond that, green productivity has significant spatial correlation in most years of the study period. Considering spatial effects, we find that there is a threshold for the impact of environmental regulation on green productivity. As regulation intensity crosses the inflection point, its effect on green productivity will change from negative to positive. Furthermore, environmental regulations may indirectly improve green productivity through technological innovation and foreign direct investment (FDI), but the effect depends upon the kind of environmental regulation imposed. Empirical results indicate that expenditure-type environmental regulation might improve green productivity by enhancing the positive effect of FDI, while investment-type environmental regulation might raise green productivity by promoting technological innovation. The results have important guiding significance for future environmental policy making.
\end{abstract}

Keywords: environmental regulation, green productivity, foreign direct investment

\section{Introduction}

Since its policy reforms of the late 1970s, China has achieved miraculous economic development and become one of the most important economies in the world. However, due to the nature of catch-up economic

*e-mail: 20171074@sxufe.edu.cn growth, the high-speed development of this economy has largely involved wasting resources [1, 2]. For example, China's GDP accounted for only about $15 \%$ of the world, but energy consumption accounted for $33 \%$ of the world, and carbon emissions accounted for $28 \%$ of the global total in 2017. Its extensive development model has also caused serious environmental pollution, greatly affecting the sustainability of this economic development - and affecting human health as well 
[3-5]. In the face of increasingly strict constraints on resources and the environment, China should accelerate transformation in patterns of economic development and promote the development of its economic growth as coordinated particularly with available resources and the environment at large [6]. The key to changing the pattern of growth and thus achieving sustainable economic development lies in improved green productivity [7].

As a revision of traditional productivity, green productivity balances economic growth with its costs on resources and the environment [8]. Improving green productivity is an effective approach to changing the mode of economic development and effective environmental regulation, along with technological innovation (TI), is a main driving force in such improvement [9]. At present, China's central government proposes an innovation-driven strategy that aims to achieve green economic growth by increasing investment in $\mathrm{R} \& \mathrm{D}$ and promoting innovation in industrial technology. Moreover, the authorities have adopted stricter environmental regulations, and more active environmental procedures, to defend the environment and conserve resources. Can technological innovation and environmental regulation enhance green productivity and promote green development? The answer to this question will undoubtedly help to formulate and promote policies related to green development strategy, and in making decisions for the next green development plan.

In facing the worsening environmental situation, there is a discussion according to which China should reflect on the consequences of attracting foreign investment strategies. Some people believe that foreign direct investment (FDI) has worsened China's environment and affected its green productivity growth. Theoretically, however, FDI may have two distinct effects on green productivity. For one, a large number of foreign investments have entered China's highly polluted and energy-intensive industries, and this has aggravated China's consumption of resources and its energy pollution, and inhibited its green productivity growth. On the other hand, foreign businesses can bring advanced technology and management methods, promote market competition and boost host countries productivity. Therefore, the impact of FDI on green productivity may depend on the host country and the intensity of environmental regulations there.

Considering that environmental regulation, technological innovation, and foreign direct investment may together have a major influence on green productivity, it is necessary to integrate these factors into a comprehensive framework for analysis. However, despite the fact that many researchers have investigated the effect of environmental regulations on green productivity, they have not revealed the mechanism by which environmental regulation may affect FDI and TI, thus affecting green productivity. Ignoring this mechanism will prevent improving explanations of the specific green development impact of environmental regulation.

In comparison to other studies, therefore, this study will contribute in three ways. First of all, considering the spatial correlation of green productivity, this paper constructs a spatial panel data model and makes an in-depth analysis on the impact of environmental regulation on green productivity from the perspective of spatial spillover effect, which makes the research conclusion more reasonable and scientific. In a secondary evaluation, it comprehensively reveal the inherent influence mechanism of environmental regulation on green productivity through FDI and technological innovation, which provides a solid theoretical basis for driving green growth by implementing green technology innovation and attracting foreign investment policies in China. Thirdly, this research divides environmental regulation into two aspects of investment-type and expenditure-type regulation and researches into the impact of different types of regulations on green productivity. It helps to clarify whether different environmental regulations have heterogeneous effects on green productivity. The results provide reference for the government to combine different types of environmental regulations to play the best role.

The rest of this study is arranged as follows. We review the relevant literature in section 2 . The empirical design - including the definition of variables, data sources, research methods, and model construction are introduced in section 3. The results and discussion are presented in section 4 . The conclusions and related policy recommendations are provided in the last chapter. The main framework of this study is shown in Fig. 1.

\section{Literature Review}

Although quite a few researchers have investigated the effectiveness of environmental regulation on green productivity in recent years, they have reached different conclusions due to their different research perspectives. Environmental regulation may encourage technological innovation, advance energy efficiency, reduce pollution emissions, and achieve green productivity improvement $[10,11]$. Some research provides evidence that environmental regulation improves green productivity [12-14]. However, other studies have found little impact or even the opposite effect $[10,15]$. In fact, no single linear relationship between green productivity and environmental regulation may necessarily exist.

For example, Xie et al. [16] used the panel threshold model to empirically examine the effect of China's environmental regulations on green productivity, finding that both command-and-control and marketbased regulations have remarkable nonlinear relationships with green productivity. Wang and Shen's [12] empirical studies showed an inverted-U relation between environmental regulation and productivity. 


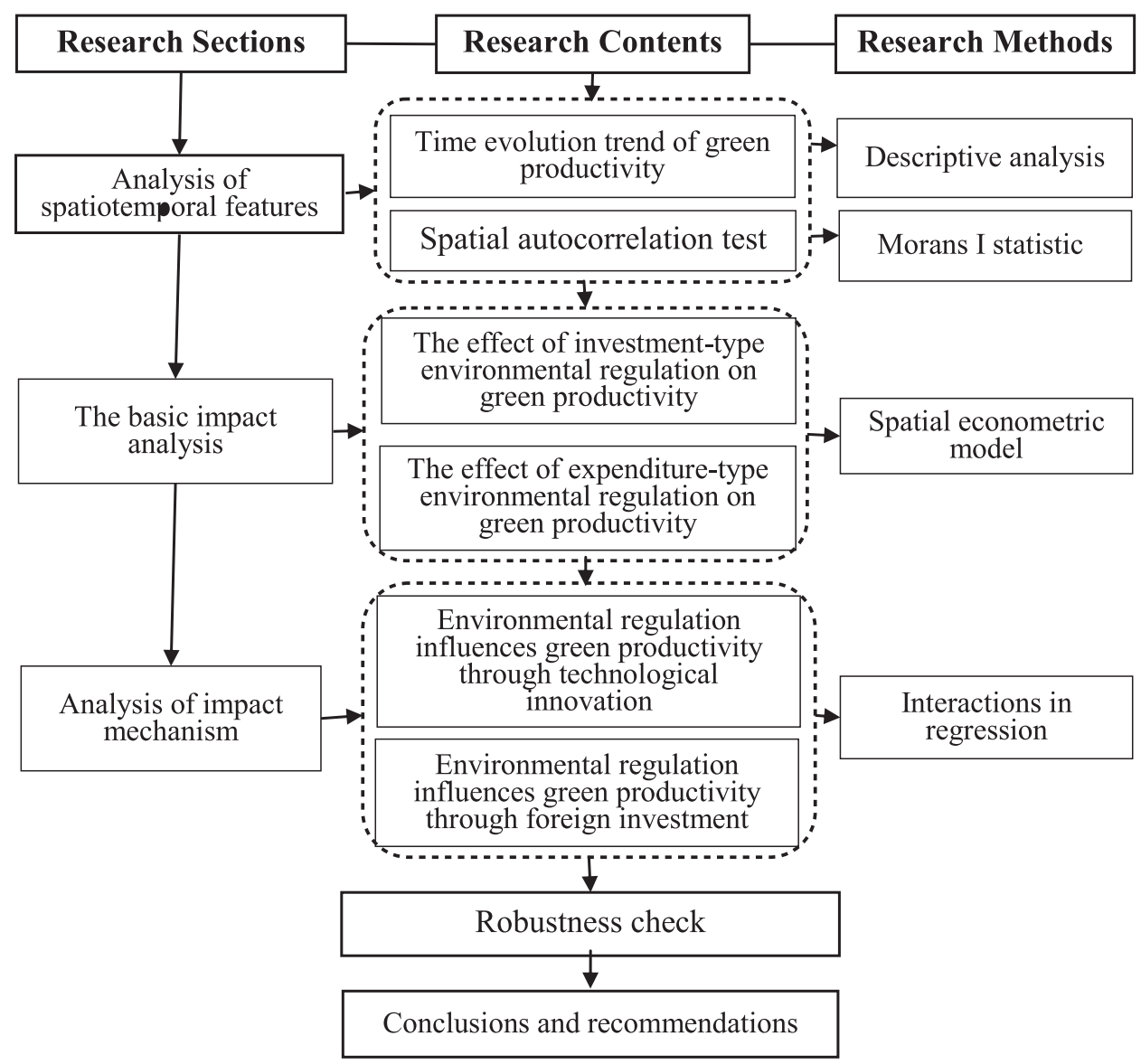

Fig. 1. The Main research framework.

Different kinds of environmental regulations generate different returns on green productivity. Arimura et al. [17] found that voluntary environmental regulation is a useful tool in reducing pollution discharge by adopting Japanese facility-level data. Zhao et al. [18] investigated the effects of three environmental regulation tools on productivity and concluded that only government subsidies and market-based regulation played active roles in the improvement of economic efficiency. Furthermore, the effect of environmental regulation on green productivity differs by region. Zhang et al. [19] discovered that market-based policy produces active effects on the growth of green productivity in eastern and central China, with western China relying mainly on administrative environmental regulations. Ren et al's [20] research results also confirmed that the effects of different environmental regulations have obvious regional differences.

Aside from environmental regulation, technological innovation is another significant factor affecting green productivity. Many studies have confirmed that technological innovation has significantly improved green productivity [21-23]. It is worth mentioning that environmental regulation may drive innovation and thus promote growth in green productivity. Based on the Porter hypothesis, environmental regulation will help companies to increase R \& D investment - and technological innovation - to compensate for the increasing costs of environmental governance [24]. Some studies have tested this hypothesis and come to verify it. For example, Lanjouw and Mody [25] found an active connection between pollution-control spending and environmental-technology patents in the United States, Germany, and Japan. Based on business survey data for seven developed countries, Lanoie et al. [26] posted a significantly active correlation between environmental innovation and the perceived seriousness of environmental regulations. Rubashkina's [27] studies, concentrating on seventeen European countries' manufacturing sectors, confirmed an active influence of environmental regulation on innovation output. Ling et al. [22] by applying data from 30 of China's provincelevel regions, found that technological innovation driven by environmental regulation positively affects green productivity.

Foreign direct investment affects the host country's green productivity through the technology spillover effect. Theoretical analysis shows that FDI's technology spillover effects mainly include competition, demonstration, personnel mobility and industrial linkage [28,29]. As results of these forms of spillover effect, FDI may help to bring advanced technology, reduce energy intensity, and improve production environment standards, all of which are beneficial for 
the improvement of green productivity [30, 31]. Besides, the entry of transnational corporations may intensify market competition and compel domestic enterprises to adopt advanced technology, improve management, and promote clean production $[32,33]$. Some empirical results suggest that FDI positively influence on host countries' green productivity. For instance, Tao et al. [34] examined the driving factors of green productivity among major cities of China and found that FDI takes an active part in prompting productivity across the Yangtze River Delta. Yuan and Xiang's [35] research confirmed that FDI takes positive affection in promoting the green productivity of China's manufacturing industry.

However, some studies have shown that FDI brings a negative consequence to green productivity. The most important topic of scholarly concern in this field is the pollution haven hypothesis. In the process of economic globalization, potential host governments tend to lower environmental standards in a "race to the bottom" to attract more foreign capital. Multinational companies pursuing maximal profits tend to transfer dirty industries to developing countries [36]. Feng and Chen [37] analyzed the factors of green industrial development by employing the spatial Durbin model, finding that FDI negatively influences green industrial productivity in China.

Other scholars have observed that FDI's mixed effects may be due to differences in host countries' environmental regulations, where strength and mode will affect the quantity and quality of foreign capital influx, leading to differences in environmental impact $[38,39]$. Raising environmental protection standards increases barriers to foreign-funded enterprises' entry and specifically restricts the entry of polluting industries. By contrast, lowered environmental regulations may attract more pollution-intensive industries. Mulatu [40] and Chung's [41] empirical studies, using cross-country data, both showed that FDI in pollution-intensive industries is more likely to occur in countries with relatively loose environmental regulation. Meanwhile, strict and suitable environmental control may motivate foreign-funded businesses to implement green technological innovation to achieve energy savings, and emission reduction [42]. By using 4200 facilities' survey data from seven OECD countries, Lanoie et al. [26] found that implementing strict environment policies stimulates environmental innovation. Moreover, compared with mandatory norms, market-based environmental regulation tools are more conducive to foreign-funded enterprises' technological innovation, and thus bring less negative environmental impact [12].

In summary, many documents focus on the associations between given factors - such as FDI, technological innovation, and environmental regulation - and productivity. Nevertheless, we seldom see scholars integrating these factors into theoretical frameworks for empirical analysis. In view of the shortcomings of the existing literature, this paper integrates green productivity, environmental regulation, technological innovation and FDI into a model and explore the mechanism of the impact of environmental regulation on green productivity. By applying a dynamic spatial panel model, the model will be capable of quantitatively evaluating the effects of regulation.

\section{Experimental Model Specification and Data}

\section{Model Specification}

Given that the environmental rule effect on green productivity may be non-linear, this study introduces the square term of environmental rule to examine the potential non-linear impact. The models are represented as follows:

$$
\begin{gathered}
\ln Y_{i t}=\beta_{1} \operatorname{lnIER}_{i t}+\beta_{2}\left(\operatorname{lnIER}_{i t}\right)^{2}+\beta_{3} \ln F D I_{i t}+\beta_{4} \operatorname{lnTI} I_{i t} \\
+\beta_{5} \ln M X_{i t}+\beta_{6} \ln E S_{i t}+\beta_{7} \ln U R_{i t}+\varepsilon_{i t}
\end{gathered}
$$

$$
\begin{aligned}
\ln Y_{i t}= & \beta_{1} \ln E E R_{i t}+\beta_{2}\left(\ln E E R_{i t}\right)^{2}+\beta_{3} \ln F D I_{i t}+\beta_{4} \ln T I_{i t} \\
& +\beta_{5} \ln M X_{i t}+\beta_{6} \ln E S_{i t}+\beta_{7} \ln U R_{i t}+\varepsilon_{i t}
\end{aligned}
$$

Among them, $Y_{i t}$ indicates the green productivity index of $I$ provinces at $T$ year; $E R$ stands for environmental regulation; while IER and EER respectively represent investment-type and expendituretype environmental regulation; FDI represents foreign direct investment; TI shows technological innovation. $M X$ is for marketization index, $E S$ for energy structure, $U R$ for urbanization rate; $\varepsilon_{i t}$ signifies a random error term.

To explore the effect mechanism, the interaction between environmental regulation and FDI is introduced into the model, expressed as follows.

$$
\begin{gathered}
\ln Y_{i t}=+\beta_{1} \ln I E R_{i t}+\beta_{2}\left(\ln I E R_{i t}\right)^{2}+\beta_{3} \ln F D I_{i t}+\beta_{4} \ln T I_{i t} \\
+\beta_{5} \ln M X_{i t}+\beta_{6} \ln E S_{i t}+\beta_{7} \ln U R_{i t}+\beta_{8} \ln (I E R \times F D I)_{i t}+\varepsilon_{i t}
\end{gathered}
$$

$\ln Y_{i t}=+\beta_{1} \ln E E R_{i t}+\beta_{2}\left(\ln E E R_{i t}\right)^{2}+\beta_{3} \ln F D I_{i t}+\beta_{4} \ln T I_{i t}$ $+\beta_{5} \ln M X_{i t}+\beta_{6} \ln E S_{i t}+\beta_{7} \ln U R_{i t}+\beta_{8} \ln (E E R \times F D I)_{i t}+\varepsilon_{i t}$

Moreover, the interaction items for environmental regulation and technological innovation can be introduced to the models, which are to be written as follows.

$$
\begin{aligned}
& \ln Y_{i t}=+\beta_{1} \ln I E R_{i t}+\beta_{2}\left(\ln I E R_{i t}\right)^{2}+\beta_{3} \ln F D I_{i t}+\beta_{4} \ln T I_{i t} \\
& +\beta_{5} \ln M X_{i t}+\beta_{6} \ln E S_{i t}+\beta_{7} \ln U R_{i t}+\beta_{8} \ln (I E R \times T I)_{i t}+\varepsilon_{i t}
\end{aligned}
$$


$\ln Y_{i t}=+\beta_{1} \ln E E R_{i t}+\beta_{2}\left(\ln E E R_{i t}\right)^{2}+\beta_{3} \ln F D I_{i t}+\beta_{4} \ln T I_{i t}$

$+\beta_{5} \ln M X_{i t}+\beta_{6} \ln E S_{i t}+\beta_{7} \ln U R_{i t}+\beta_{8} \ln (E E R \times T I)_{i t}+\varepsilon_{i t}$

\section{Spatial Econometric Approaches}

Considering that spatial spillover of local green productivity may affect neighboring localities' green productivity, the common spatial econometric models for spatial error (SEM) and spatial lag (SLM) can help to analyze the affect mechanism of environmental regulation on green productivity. Given that changes in green productivity may have a time-lag effect, this paper introduces the green productivity variable's lag phase into the standard space panel model.

The SLM model is defined as follows:

$$
y_{i t}=\theta y_{i, t-1}+\rho \sum_{j=1}^{N} W_{i t} y_{i t}+\gamma X_{i t}+a_{i}+v_{t}+\varepsilon_{i t}
$$

Here, $\theta$ is lag coefficient, implying the impact of the previous period's dependent variable level on the current period; $\rho$ shows the spatial lag coefficient, and the spatial weight matrix is represented by $W$. The independent variable is represented by $X$; the terms $\alpha_{i}$ and $v_{t}$ respectively represent a regional fixed effect and a time period-specific effect; $\varepsilon_{i t}$ is the random error term. form:

The SEM model may be written in the following

$$
\begin{gathered}
y_{i t}=\theta y_{i, t-1}+\gamma X_{i t}+a_{i}+v_{t}+\psi_{i t} \\
\psi_{i t}=\eta \sum_{j=1}^{N} W_{i t} \psi_{i t}+\varepsilon_{i t}
\end{gathered}
$$

Among the terms here, $\psi_{i t}$ is for spatially autocorrelated error; $\eta$ is for spatial error term's autoregressive coefficient.

Considering that there may be a two-way causal relationship between key independent variables and dependent variables, which may cause biased estimation results, this study will solve possible endogenous problems in spatial dynamic panel models by employing the system generalized moment estimation method (SGMM).

\section{Constructing the Spatial Weight Matrix}

For the estimation of the spatial econometric model, it is very important to build a reasonable spatial weight matrix. We set an ordinary, geographically adjacent weight matrix for this study's main empirical analysis, and established a geographic distance weight matrix in order to test robustness. The geographic adjacency weight matrix is as follows.

$$
\mathrm{W}_{1}=\left[\begin{array}{cccc}
w_{11} & w_{12} & \ldots & w_{1 n} \\
w_{21} & w_{22} & \ldots & w_{2 n} \\
\vdots & \vdots & \vdots & \vdots \\
w_{n 1} & w_{n 2} & \ldots & w_{n n}
\end{array}\right]
$$

Here, $n$ represents the total number of areas to be studied, while $W_{i j}(\mathrm{i}, \mathrm{j}=1,2, \ldots, \mathrm{n})$ indicates the adjacent situation of region $i$ and region $j$. If they have common vertices or common edges, then between region $i$ and region $j, w_{i j}=1$; if not, $w_{i j}=0$.

In order to test robustness, we set the weight matrix according to geographical distance between regions. The geographic distance weight matrix is set as follows.

$$
w_{2}=D_{i j} / \sum_{j=1}^{N} D_{i j}
$$

Here, $D_{i j}$ denotes the railway mileage between provincial capitals $i$ and $j$.

\section{Selection of Variables and Collection of Data}

\section{Dependent Variable}

To measure green productivity, it is first necessary to construct a set of production possibilities that include both expected and undesired outputs. Based on Oh's [43] suggestion, the Global Malmquist-Luenberger (GML) index can evaluate green productivity. The GML index is written as follows.

$$
G M L_{t}^{t+1}=\frac{1+D^{G}\left(x^{t}, y^{t}, b^{t}\right)}{1+D^{G}\left(x^{t+1}, y^{t+1}, b^{t+1}\right)}
$$

Here, $x$ are the input variables; $y$ mark expected output variables, and $b$ shows unexpected output variables.

The input factors include labor force, energy consumption and capital stock, using total end-ofyear employment to estimate labor force input while capital stock is obtained by the perpetual inventory method. Total energy consumption is taken as energy consumption input; the constant-price GDP is a measure of expected output, whereas unexpected outputs arise from pollutant emission indices including those for wastewater, waste gas, and solid waste. The definitions and statistics of input and output variables are shown in Table 1.

\section{Independent Variable}

As to the explanatory variables in this study, there is at present no consensus in academic circles on the measurement of environmental regulation. According to different classification standards, environmental regulations may be divided into different types. Böcher [44] classified broad environmental regulations into four types: persuasive, cooperative, economic, and 
Table 1. Definition and statistics of input and output variables.

\begin{tabular}{|c|c|c|c|c|}
\hline Variable & Indicator & Measure & Unit & Mean \\
\hline & Labor force & Estimated by total employment & $10^{4}$ person & 2483 \\
\hline Input & Capital stock & Calculated by perpetual inventory method & $10^{8}$ yuan & 26175 \\
\hline Desirable output & Energy consumption & Total energy consumption & $10^{4}$ tons tce & 10797 \\
\hline Undesirable output & Pollutants discharge & $\begin{array}{c}\text { Constructing comprehensive environmental pollution } \\
\text { emissions by using entropy method weighting }\end{array}$ & $-10^{8}$ yuan & 12533 \\
\hline
\end{tabular}

regulatory. Of these, economic environmental regulation is generally considered (by the academic community) to be superior to other categories for the internalization of external costs. Böhringer et al. [45] further divided economic environmental regulations into expendituretype and investment-type environmental regulations. Expenditure-type environmental regulation is mainly based on the perspective of costs, and generally functions through the purchase of pollutant emission rights, or payment of environment-relevant taxes. Investment-type environmental regulation refers to environment-related investment that has long-term effects on enterprises and forms the fixed assets of enterprises with the aim of reducing environmental damage in production.

Taking into account the relative perfection of indicators and the limited availability of data in Chinese contexts, this study discusses only economic environmental regulations, dividing them into expenditure and investment types. We measure investment-type environmental regulation by the ratio of industrial pollution treatment investment to industrial output value. The proportion of income from waste discharge fees to industrial output value is employed to estimate the intensity of expenditure-type environmental regulations.

Meanwhile, FDI is represented as the proportion of foreign direct investment actually utilized in GDP. Energy structure is expressed by the share of coal in total energy consumption. Technological innovation is

Table 2. The explanation and descriptive statistics of variables.

\begin{tabular}{|c|c|c|c|c|c|}
\hline Variable & Unit & Mean & Std. dev. & Min & Max \\
\hline $\ln$ GML & - & 0.808 & 0.107 & 0.52 & 1.226 \\
\hline $\operatorname{lnIER}$ & 104 yuan & 0.340 & 0.207 & 0.353 & 1.349 \\
\hline $\operatorname{lnEER}$ & 104 yuan & 0.125 & 0.084 & 0.009 & 0.611 \\
\hline $\operatorname{lnFDI}$ & $\%$ & 3.152 & 1.036 & -0.207 & 5.176 \\
\hline $\operatorname{lnTI}$ & $\%$ & 0.756 & 0.358 & -0.141 & 1.967 \\
\hline $\operatorname{lnMX}$ & - & 1.948 & 0.357 & 0.863 & 2.708 \\
\hline $\operatorname{lnES}$ & $\%$ & 4.494 & 0.385 & 2.499 & 5.313 \\
\hline $\operatorname{lnUR}$ & $\%$ & 3.871 & 0.289 & 3.198 & 4.495 \\
\hline
\end{tabular}

represented by R \& D expenditure as a share of GDP. The ratio of urban population in total population is taken as the urbanization rate. The marketization index is obtained from the "Report on China's Provincial Marketization Index."

In view of the availability of data, the samples of this study come from 30 provincial administrative regions, representing most of mainland China except for the Tibet autonomous region. All data cover the period 2001-2016. In addition, all variables describe annual values and are expressed in a logarithmic form. Each per-capita variable was obtained by dividing each actual total variable by the total population. As a summary, the explanation and statistical description of the variables in this study are shown in Table 2 .

\section{Results and Discussion}

\section{Spatial and Temporal Characteristics of Green Productivity}

As Fig. 2 shows, the GML index shows an increasing trend for China across the sample period. One explanation for the trend could be that the government has implemented environmental policies, such as energy saving and emissions reduction, while promoting rapid economic growth in China. Surprisingly, there was a marked decline in 2009, possibly the result of shock on China's economy from the global financial crisis. To maintain stable economic growth, the government has promoted the expansion of energy-intensive industries or pollution-intensive industries. Comparing different regions, there are obvious gradient change characteristics for the green productivity index in broad regions: the eastern region's green productivity growth is fastest, the west being the slowest, and the middle taking the second place. It is worth noting that since 2009 the gap appears to be widening between the eastern region and each of the others. This may be because the eastern region took the lead in implementing the innovation strategy and upgrading the industrial structure, while the central and western regions are in a rapid industrial process and have accepted the mass polluting enterprises in the eastern region. 


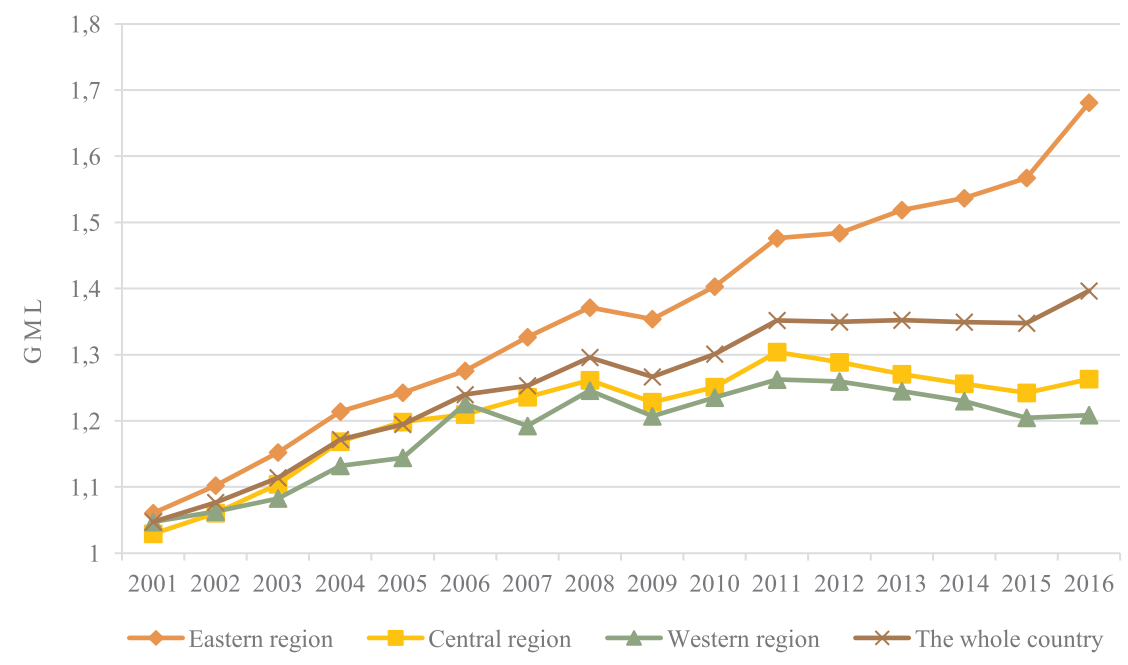

Fig. 2. The trend of cumulative growth for green productivity in China from 2001 to 2016.

In order to more clearly show the inter-provincial differences, this paper combines the actual size of each year's provincial green productivity index. It uses the "natural discontinuity" method to divide the 30 provinces into five levels, representing low-value areas, lower-value areas, median areas, higher-value areas, and highest-value areas (see Fig. 3). As can be seen from Fig. 3, Beijing has the highest cumulative GML index in all time, while a higher green productivity growth has been maintained in Shandong, Shanghai, Jiangsu and Guangdong provinces for most of the time. There is also a remarkable phenomenon by which high-growth areas of green productivity have gradually gathered in coastal and central areas as time goes on. One possible explanation for this situation is that the economically developed provinces in coastal areas of China have adopted more advanced production technologies and promoted the optimization and adjustment of industrial structures. In the meantime, the central and western regions have (in sequence) undertaken industrial transfer from the eastern region, and most of these transferred industries are highly pollutant and energyintensive.

\section{Spatial Autocorrelation Test}

Before performing spatial econometric analysis, it is worth performing a spatial autocorrelation test on the explanatory variables. This article uses Moran's I statistic to examine spatial autocorrelation.

As seen from Table 3, the Moran's I values are all positive and pass the $1 \%$ significance level test except in 2001 and 2002, suggesting there are spatial autocorrelations in the green productivity index.

Spatial autocorrelation test results show that if the spatial dimension correlation and heterogeneity are not considered in model, the estimation results will inevitably deviate from reality. It is therefore necessary to incorporate spatial correlation into the analytic framework for environmental regulation and GML. To compare SLM and SEM models, we conducted Lagrange multiplier (LM) and Robust Lagrange multiplier (Robust LM) tests of the spatial econometric estimators. The LM lag test results were more significant than those of the LM error tests in four models under the geographic adjacency weight matrix (W1) setting, as shown in Table 4. Similar conclusions were drawn from the Robust LM tests. For this study, the results indicate that the SLM model is better than SEM for the sample data, supporting SLM's adoption for the subsequent analysis.

\section{Impact of Environmental Regulation on Green Productivity}

As Table 5 and Table 6 show, the time-lag term coefficients of GML are positive and significant, suggesting that GML shows significant time-lag effects. If the last GML is at a high level, the next GML may continue to rise. This not only shows that green productivity growth is a cumulative process, but also confirms the rationality of model selection. The coefficients in W. GML are positive and through significance inspection with a threshold of $1 \%$, meaning that green productivity has spatial spillover effects. As capital, labor, information, technology, and other aspects show more interaction between neighboring areas in geographical location, they may lead to the spatial diffusion of green technology, and thus produce the spatial spillover effect of green productivity. These results show that the green productivity level of one region is not only affected by its own factors, but also by the green productivity level of neighboring regions.

At 5\% significance level, the coefficients for investment-type environmental regulation and its square term are (respectively) negative and positive in Table 5. These results show that investment-type environmental regulation and green productivity take a prominent U-shaped curve relationship. That is to say, the effect of investment-type environmental regulation on green 
a)

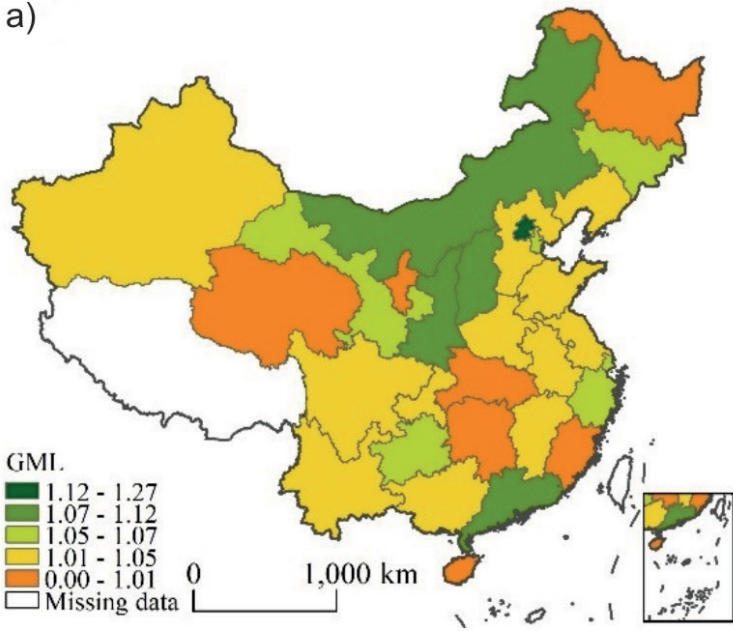

c)

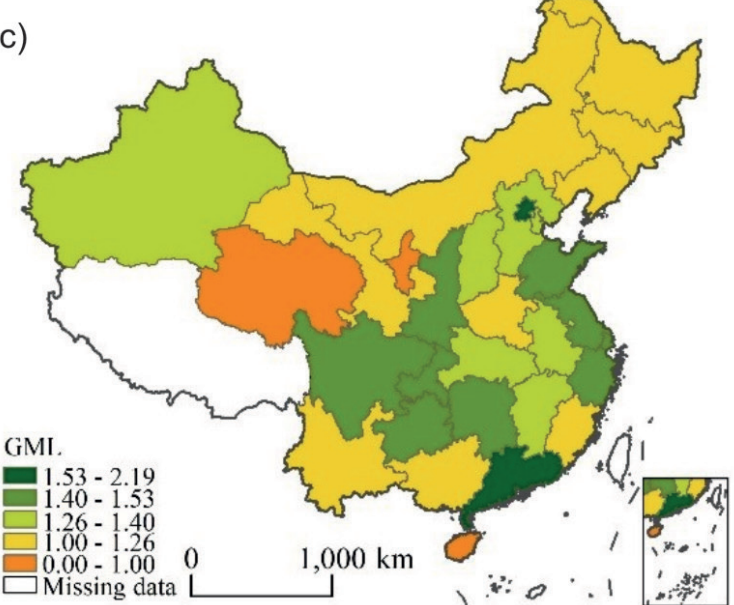

b)
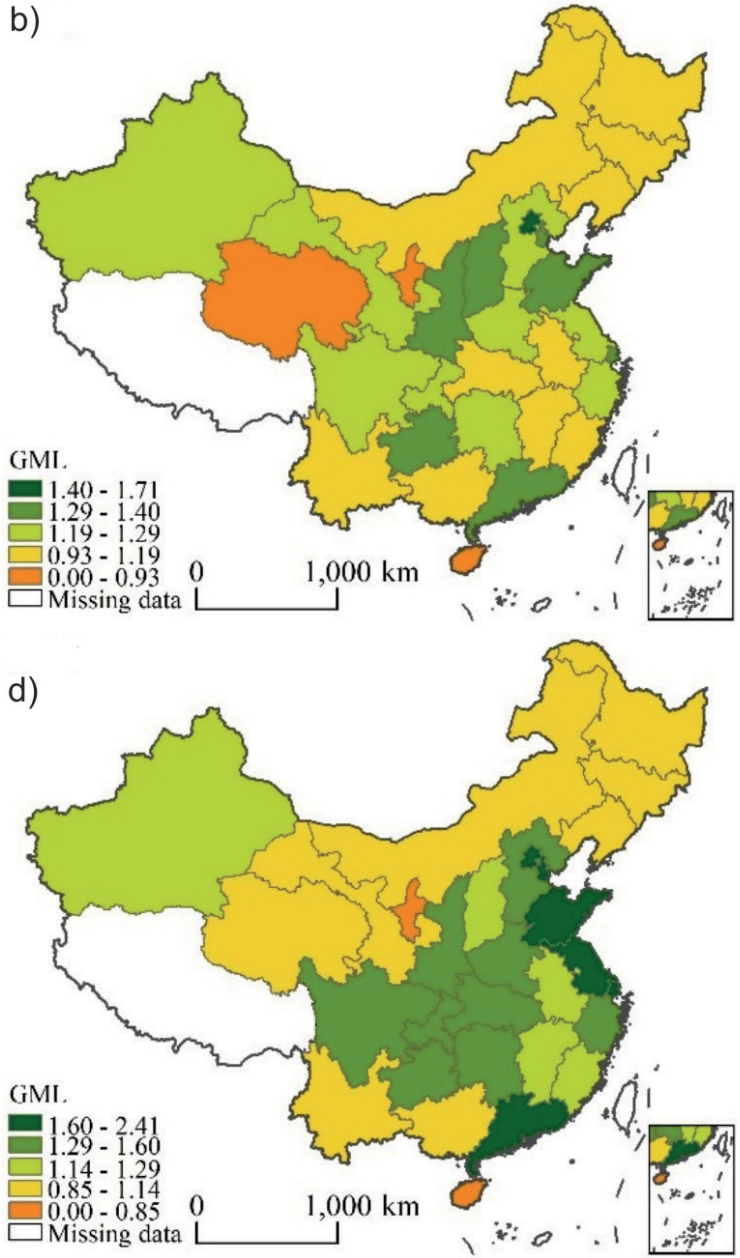

Fig. 3. The spatial distribution of green productivity in a) 2001, b) 2006, c) 2011 and d) 2016.

productivity shows a threshold below which increasing investment in pollution control will have the opposite effect in terms of improving green productivity. When above the threshold, increasing investments in pollution control will improve green productivity. Indeed, before the inflection point of the U-shaped curve, investment in industrial pollution control is at a low level, and the effective environmental improvement was very weak. In addition, increased investment in pollution control would squeeze expenditures on production, and this effect is not conducive to growth, meaning that the strengthening of regulations would lead to a decline in green productivity. After this inflection point, however, the investment in industrial wastewater, waste gas, solid waste and other treatment projects is at a high level. In particular, both government and enterprise have accumulated rich experience and technologies for environmental treatment. Therefore,

Table 3. The results of spatial dependence test.

\begin{tabular}{|c|c|c|c|c|c|c|c|}
\hline Year & Moran's I & $\mathrm{Z}$ & $\mathrm{P}$ & year & Moran's I & $\mathrm{Z}$ & $\mathrm{P}$ \\
\hline 2001 & -0.014 & 0.249 & 0.402 & 2009 & 0.131 & 3.618 & 0.000 \\
\hline 2002 & -0.013 & 3.007 & 0.000 & 2010 & 0.109 & 4.238 & 0.000 \\
\hline 2003 & 0.037 & 2.108 & 0.018 & 2011 & 0.122 & 4.473 & 0.000 \\
\hline 2004 & 0.092 & 1.791 & 0.037 & 2012 & 0.130 & 4.105 & 0.000 \\
\hline 2005 & 0.106 & 4.225 & 0.000 & 2013 & 0.143 & 1.437 & 0.075 \\
\hline 2006 & 0.117 & 4.530 & 0.000 & 2014 & 0.156 & 2.108 & 0.000 \\
\hline 2007 & 0.126 & 4.536 & 0.000 & 2015 & 0.217 & 2.681 & 0.004 \\
\hline 2008 & 0.125 & 3.378 & 0.000 & 2016 & 0.303 & 2.773 & 0.003 \\
\hline
\end{tabular}


Table 4. LM Test of Spatial Panel Model.

\begin{tabular}{|c|c|c|c|c|c|c|c|c|}
\hline & LM-lag & P-value & Robust LM-lag & P-value & LM-error & P-value & Robust LM-error & P-value \\
\hline Model 1 & $9.126^{* * *}$ & 0.003 & $6.556^{* * *}$ & 0.010 & $9.056^{* * *}$ & 0.003 & $6.486^{* *}$ & 0.011 \\
\hline Model 2 & $16.499 * * *$ & 0.000 & $14.738^{* * *}$ & 0.000 & $2.774 *$ & 0.096 & 1.013 & 0.314 \\
\hline Model 3 & $9.088^{* * *}$ & 0.003 & $6.562 * * *$ & 0.010 & $8.795^{* * *}$ & 0.003 & $6.268^{* *}$ & 0.012 \\
\hline Model 4 & $17.944 * * *$ & 0.000 & $16.093 * * *$ & 0.000 & $2.806^{*}$ & 0.094 & 0.956 & 0.328 \\
\hline Model 5 & $17.108^{* * *}$ & 0.000 & $6.599 * *$ & 0.010 & $14.477 * * *$ & 0.000 & $3.968^{* *}$ & 0.046 \\
\hline Model 6 & $15.046^{* * *}$ & 0.000 & $8.128^{* * *}$ & 0.004 & $11.569 * * *$ & 0.001 & $4.651^{* *}$ & 0.031 \\
\hline
\end{tabular}

Note: $* * * \mathrm{p}<0.01, * * \mathrm{p}<0.05, * \mathrm{p}<0.1$

the effect of environmental pollution control would begin to appear.

On the basis of the regression results, it's not hard to work out the turning point of investment-type environmental regulation for GML is approximately 0.78 . At present, the investment-type regulation levels of these Chinese provinces all stand in the left side of the U curve - all except for the Ningxia Autonomous Region. This result shows that the intensity of investment-type regulation is relatively low, and it still has much room for improvement according to China's industrial pollution control investment.

Table 5. The empirical results of IER, FDI and GML.

\begin{tabular}{|c|c|c|c|c|c|}
\hline Determinants & $\begin{array}{l}\text { Pool model } \\
\text { (ols) }\end{array}$ & $\begin{array}{l}\text { Panel Models } \\
\text { (fixed effects) }\end{array}$ & $\begin{array}{c}\text { Dynamic panel model } \\
(\mathrm{SGMM})\end{array}$ & $\begin{array}{l}\text { Spatial Panel } \\
\text { Model(ML) }\end{array}$ & $\begin{array}{l}\text { Spatial dynamic panel model } \\
\text { (SGMM) }\end{array}$ \\
\hline \multirow[t]{2}{*}{ L.InGML } & & & $0.460 * * *$ & & $0.518 * * *$ \\
\hline & & & $(0.006)$ & & $(0.000)$ \\
\hline \multirow[t]{2}{*}{ W. $\operatorname{lnGML}$} & & & & $0.012 * *$ & $0.034 * * *$ \\
\hline & & & & $(0.050)$ & $(0.000)$ \\
\hline \multirow[t]{2}{*}{$\operatorname{lnIER}$} & 0.015 & $-0.143 * * *$ & $-0.061 * *$ & $0.004 *$ & $-0.074 * * *$ \\
\hline & $(0.717)$ & $(0.000)$ & $(0.049)$ & $(0.09)$ & $(0.000)$ \\
\hline \multirow[t]{2}{*}{$(\operatorname{lnIER})^{2}$} & $-0.091 * *$ & $0.139 * * *$ & 0.026 & $-0.087 * *$ & $0.047 * * *$ \\
\hline & $(0.019)$ & $(0.000)$ & $(0.354)$ & $(0.024)$ & $(0.000)$ \\
\hline \multirow[t]{2}{*}{$\operatorname{lnFDI}$} & $-0.027 * * *$ & -0.005 & 0.006 & $-0.027 * * *$ & $0.003 * *$ \\
\hline & $(0.000)$ & $(0.235)$ & $(0.256)$ & $(0.000)$ & $(0.043)$ \\
\hline \multirow[t]{2}{*}{ LnTI } & $0.191 * * *$ & $0.182 * * *$ & $0.109 * *$ & $0.196 * * *$ & $0.113 * * *$ \\
\hline & $(0.000)$ & $(0.000)$ & $(0.034)$ & $(0.000)$ & $(0.000)$ \\
\hline \multirow[t]{2}{*}{$\operatorname{lnMX}$} & $0.137 * * *$ & $0.127 * * *$ & $0.137 * * *$ & $0.121 * * *$ & $0.075 * * *$ \\
\hline & $(0.000)$ & $(0.000)$ & $(0.002)$ & $(0.000)$ & $(0.000)$ \\
\hline \multirow[t]{2}{*}{$\ln E S$} & $-0.027 * * *$ & $-0.088 * * *$ & $-0.035^{*}$ & $-0.027 * * *$ & $-0.048 * * *$ \\
\hline & $(0.002)$ & $(0.000)$ & $(0.087)$ & $(0.003)$ & $(0.000)$ \\
\hline \multirow[t]{2}{*}{$\ln U R$} & $-0.092 * * *$ & $-0.079 * *$ & $-0.166^{* *}$ & $-0.09 * * *$ & $-0.169 * * *$ \\
\hline & $(0.000)$ & $(0.015)$ & $(0.019)$ & $(0.000)$ & $(0.000)$ \\
\hline \multirow[t]{2}{*}{ Constant } & $0.849 * * *$ & $1.146 * * *$ & $0.919 * * *$ & & $0.930 * * *$ \\
\hline & $(0.000)$ & $(0.000)$ & $(0.000)$ & & $(0.000)$ \\
\hline \multirow[t]{2}{*}{ Sargan } & & & & & 26.547 \\
\hline & & & & & {$[1.000]$} \\
\hline
\end{tabular}

Note: $* * * \mathrm{p}<0.01, * * \mathrm{p}<0.05, * \mathrm{p}<0.1$ 
The regression coefficients of the first term and the square term of expenditure-type regulation are significantly negative and positive in Table 6, respectively. Similar to the investment-type environmental regulation, the expenditure-type regulation and GML also presented a U-shaped relationship. One possible reason can explain this result. On the left-hand side of $U$ curve, the sewage charge is lower, meaning a company's default cost will be lower, leaving the company with a lack of motivation for green innovation. In addition, the collection of a sewage charge directly increases the cost of an enterprise, resulting in harm to green productivity growth. However, as sewage charges continue to increase and exceed thresholds, the situation will stimulate companies to increase R \& $\mathrm{D}$ investment, to introduce new technologies and new processes, and to further optimize resource allocation in order to increase green productivity. As a result, expenditure-type environmental regulation promotes the transition from short-term cost increases to longterm R \& D incentives, and ultimately achieves green growth, which confirms the Porter hypothesis.

It's easy to get that the inflection point is 0.32 . According to the statistics for 2016, no province has yet exceeded the inflection point. The result is similar to that of Hou and Chen [46], which find that the current standard of discharge fee is not effective in pollution control in China. This means that China should further enhance the intensity of its expenditure-type regulation and promote green technological innovation. In fact, with the increase of waste charges, the pressure on enterprises is increasing, and this will force enterprises to reduce the intensity of their pollutant emissions through technological innovation in order to pursue higher profit levels [16]. As a result, appropriate environmental regulations lead to cost-effective innovation in green technology, thus improving green productivity.

In general, there is a nonlinear relationship between the green productivity and the investment-type environment and the expenditure-type environment regulation. These results are slightly similar to those

Table 6. The empirical results of EER, FDI and GML.

\begin{tabular}{|c|c|c|c|c|c|}
\hline Determinants & $\begin{array}{l}\text { Pool model } \\
\text { (ols) }\end{array}$ & $\begin{array}{l}\text { Panel Models } \\
\text { (fixed effects) }\end{array}$ & $\begin{array}{l}\text { Dynamic panel model } \\
\text { (SGMM) }\end{array}$ & $\begin{array}{l}\text { Spatial Panel } \\
\text { Model(ML) }\end{array}$ & $\begin{array}{l}\text { Spatial dynamic panel model } \\
\text { (SGMM) }\end{array}$ \\
\hline \multirow[t]{2}{*}{ L.InGML } & & & $0.432 * * *$ & & $0.588 * * *$ \\
\hline & & & $(0.005)$ & & $(0.000)$ \\
\hline \multirow[t]{2}{*}{ W. $\operatorname{lnGML}$} & & & & -0.043 & $0.028 * * *$ \\
\hline & & & & $(0.386)$ & $(0.003)$ \\
\hline \multirow[t]{2}{*}{$\operatorname{lnEER}$} & $-0.268 * *$ & -0.375 & -0.177 & $-0.258 * *$ & $-0.234 * * *$ \\
\hline & $(0.121)$ & $(0.001)$ & $(0.112)$ & $(0.035)$ & $(0.001)$ \\
\hline \multirow[t]{2}{*}{$(\operatorname{lnEER})^{2}$} & 0.739 & $0.811 * * *$ & $0.342 * *$ & $0.726 * * *$ & $0.367 * * *$ \\
\hline & $(0.231)$ & $(0.000)$ & $(0.031)$ & $(0.0020$ & $(0.004)$ \\
\hline \multirow[t]{2}{*}{$\operatorname{lnFDI}$} & $-0.021 * * *$ & -0.004 & 0.007 & $-0.019 * * *$ & $0.002 *$ \\
\hline & $(0.004)$ & $(0.360)$ & $(0.155)$ & $(0.000)$ & $(0.052)$ \\
\hline \multirow[t]{2}{*}{ LnTI } & $0.189 * *$ & $0.179 * * *$ & $0.132 * *$ & $0.193 * * *$ & $0.08^{* * *}$ \\
\hline & $(0.013)$ & $(0.000)$ & $(0.011)$ & $(0.000)$ & $(0.001)$ \\
\hline \multirow[t]{2}{*}{$\operatorname{lnMX}$} & $0.144 * *$ & $0.118 * * *$ & $0.122 * * *$ & $0.131 * * *$ & $0.069 * * *$ \\
\hline & $(0.014)$ & $(0.000)$ & $(0.006)$ & $(0.000)$ & $(0.000)$ \\
\hline \multirow[t]{2}{*}{$\operatorname{lnES}$} & $-0.034 * * *$ & $-0.093 * * *$ & $-0.035^{*}$ & $-0.038 * * *$ & $-0.056^{* * *}$ \\
\hline & $(0.009)$ & $(0.000)$ & $(0.079)$ & $(0.000)$ & $(0.000)$ \\
\hline \multirow[t]{2}{*}{$\operatorname{lnUR}$} & $-0.107 * *$ & $-0.075^{* *}$ & $-0.158 * *$ & $-0.110 * * *$ & $-0.167 * * *$ \\
\hline & $(0.018)$ & $(0.029)$ & $(0.034)$ & $(0.000)$ & $(0.000)$ \\
\hline \multirow[t]{2}{*}{ Constant } & $0.939^{*}$ & $1.176^{* * *}$ & $0.922 * * *$ & & $0.960 * * *$ \\
\hline & $(0.077)$ & $(0.000)$ & $(0.001)$ & & $(0.000)$ \\
\hline \multirow[t]{2}{*}{ Sargan } & & & & & 26.006 \\
\hline & & & & & {$[1.000]$} \\
\hline
\end{tabular}

Note: $* * * \mathrm{p}<0.01, * * \mathrm{p}<0.05,{ }^{*} \mathrm{p}<0.1$ 
found by Xie et.al [16] and Li and Ramakrishnan [47]. Their conclusions confirm a nonlinear relationship between market-based regulation and command-andcontrol regulation and green productivity in China. These indicate that government departments should enhance the regulation intensity and promote the role of green productivity of environmental regulation from negative to positive.

For FDI, the estimated coefficients are remarkably positive in Table 5 and Table 6. These results imply that the FDI inflow has dramatically boosted the growth of green productivity in China. This conclusion is consistent with $\mathrm{Li}$ and Wu's [11] conclusion, which found that FDI has a positive impact on green productivity of Chinese major cities. The main reason for this result is that the FDI influx has brought a great deal of capital to China and injected new vitality into the country's rapid economic growth. Moreover, the advances brought about by FDI - in technology for production and environmental protection, and in management experience - may drive local enterprises to carry out cleaner production and to promote green technology. The progress and growth could develop through demonstration-imitation, market competition, human flow training, and industrial linkages.

For other variables, as expected, technological innovation positively influence on GML. Many scholars have also confirmed this conclusion [48-50]. It is well known that technological innovation, especially green technological innovation, is beneficial for the improved efficiency in use resources and for the ability to control pollution, thereby lending to green productivity. A higher degree of marketization improved the market competition environment, enabling enterprises to compete fairly in the market; at the same time, it may also optimize the allocation of resources in the market and boost green productivity. There exists a significant negative relation between energy structure and green productivity: heavier coal consumption brings more pollutant emissions and will negatively affect green productivity growth. The regression coefficient of urbanization is significantly negative, indicating that the negative impact of urbanization on green productivity exceeds its positive impact. In fact, China's rapid urbanization has caused many problems including traffic congestion, environmental pollution and overconsumption of energy.

\section{Analysis of Mechanism of Environmental Regulation Affecting Green Productivity}

As shown in Table 7, the trend of interaction between FDI and expenditure-type regulation is remarkably positive, indicating that the improvement of expenditure-type environmental regulation intensity may enhance the positive influence of FDI on green

Table 7. The result of regulatory effect of environmental regulation.

\begin{tabular}{|c|c|c|c|c|c|c|c|c|}
\hline Determinants & Model 3 & & Model 4 & & Model 5 & & Model 6 & \\
\hline L. $\operatorname{lnGML}$ & $0.517 * * *$ & $(0.000)$ & $0.516^{* * *}$ & $(0.000)$ & $0.568 * * *$ & $(0.000)$ & $0.553 * * *$ & $(0.000)$ \\
\hline W. $\operatorname{lnGML}$ & $0.033 * * *$ & $(0.000)$ & $0.34 * * *$ & $(0.002)$ & $0.037 * * *$ & $(0.000)$ & $0.024 * * *$ & $(0.002)$ \\
\hline $\operatorname{lnIER}$ & $-0.075 * * *$ & $(0.000)$ & & & $-0.132 * * *$ & $(0.000)$ & 0.073 & $(0.705)$ \\
\hline$(\operatorname{lnIER})^{2}$ & $0.044 * * *$ & $(0.000)$ & & & $0.0632 * * *$ & $(0.000)$ & 0.031 & $(0.888)$ \\
\hline $\operatorname{lnEER}$ & & & $-0.281 * * *$ & $(0.000)$ & & & & \\
\hline$(\operatorname{lnEER})^{2}$ & & & $0.430 * * *$ & $(0.038)$ & & & & \\
\hline $\operatorname{lnFDI}$ & 0.003 & $(0.253)$ & 0.004 & $(0.463)$ & 0.001 & $(0.368)$ & $0.002 *$ & $(0.082)$ \\
\hline LnTI & $0.113 * * *$ & $(0.000)$ & $0.111 * * *$ & $(0.000)$ & $0.049 * *$ & $(0.016)$ & $0.111 * * *$ & $(0.000)$ \\
\hline $\operatorname{lnMX}$ & $0.076 * * *$ & $(0.000)$ & $0.080 * * *$ & $(0.000)$ & $0.073 * * *$ & $(0.000)$ & $0.072 * * *$ & $(0.000)$ \\
\hline $\ln E S$ & $-0.048 * * *$ & $(0.000)$ & $-0.062 * * *$ & $(0.000)$ & $-0.501 * * *$ & $(0.000)$ & $-0.059 * * *$ & $(0.000)$ \\
\hline $\ln U R$ & $-0.169 * * *$ & $(0.000)$ & $-0.185 * * *$ & $(0.000)$ & $-0.152 * * *$ & $(0.000)$ & $-0.149 * * *$ & $(0.000)$ \\
\hline lnIER.FDI & -0.002 & $(0.660)$ & & & & & & \\
\hline lnEER.FDI & & & $0.017 * *$ & $(0.042)$ & & & & \\
\hline lnIER.TI & & & & & $0.062 *$ & $(0.099)$ & & \\
\hline lnEER.TI & & & & & & & -0.249 & $(0.12)$ \\
\hline Constant & $0.933 * * *$ & $(0.000)$ & $1.058 * * *$ & $(0.000)$ & $0.875 * * *$ & $(0.000)$ & $0.921 * * *$ & $(0.000)$ \\
\hline Sargan & 26.633 & {$[1.000]$} & 25.833 & {$[1.000]$} & 23.809 & {$[1.000]$} & 26.483 & [1.000] \\
\hline Sample & 480 & & 480 & & 480 & & 480 & \\
\hline
\end{tabular}

Note: $* * * \mathrm{p}<0.01, * * \mathrm{p}<0.05, * \mathrm{p}<0.1$ 
productivity. Where the level of expenditure-type regulation is low, polluting industry will transfer to the region and aggravate environmental pollution there. Accordingly, strict environmental regulation raises the threshold for FDI entry and plays a screening role in FDI transactions [51]. As a result, FDI which is beneficial to technological upgrading and environmental protection will be introduced preferentially, while FDI flowing

Table 8 . The robustness test results.

\begin{tabular}{|c|c|c|c|c|c|c|}
\hline Variables & Model 1 & Model 2 & Model 3 & Model 4 & Model 5 & Model 6 \\
\hline \multirow[t]{2}{*}{ L. $\operatorname{lnGML}$} & $0.505 * * *$ & $0.507 * * *$ & $0.497 * * *$ & $0.534 * * *$ & 0.545 & 0.554 \\
\hline & $(0.000)$ & $(0.000)$ & $(0.000)$ & $(0.000)$ & $(0.000)$ & $(0.000)$ \\
\hline \multirow[t]{2}{*}{ W. $\operatorname{lnGML}$} & $0.342 * * *$ & $0.347 * * *$ & $0.358 * * *$ & $0.340 * * *$ & 0.033 & 0.024 \\
\hline & $(0.000)$ & $(0.000)$ & $(0.000)$ & $(0.000)$ & $(0.000)$ & $(0.002)$ \\
\hline \multirow[t]{2}{*}{ lnIER } & $-0.055 * * *$ & & $-0.056 * * *$ & & -0.081 & \\
\hline & $(0.000)$ & & $(0.000)$ & & $(0.000)$ & \\
\hline \multirow[t]{2}{*}{$(\ln I E R)^{2}$} & $0.030 * * *$ & & $0.037 * * *$ & & 0.050 & \\
\hline & $(0.000)$ & & $(0.001)$ & & $(0.000)$ & \\
\hline \multirow[t]{2}{*}{$\operatorname{lnEER}$} & & $-0.153 * *$ & & $-0.177 * *$ & & 0.073 \\
\hline & & $(0.017)$ & & $(0.047)$ & & $(0.705)$ \\
\hline \multirow[t]{2}{*}{$(\operatorname{lnEER})^{2}$} & & $0.269 * *$ & & $0.170 * *$ & & 0.031 \\
\hline & & $(0.021)$ & & $(0.023)$ & & $(0.888)$ \\
\hline \multirow[t]{2}{*}{$\operatorname{lnFDI}$} & $0.003 *$ & $0.004 * *$ & 0.002 & 0.008 & 0.001 & 0.003 \\
\hline & $(0.050)$ & $(0.037)$ & $(0.465)$ & $(0.104)$ & $(0.382)$ & $(0.182)$ \\
\hline \multirow[t]{2}{*}{ LnTI } & $0.087 * * *$ & $0.096 * * *$ & $0.087 * * *$ & $0.077 * *$ & 0.111 & 0.118 \\
\hline & $(0.001)$ & $(0.000)$ & $(0.001)$ & $(0.018)$ & $(0.000)$ & $(0.000)$ \\
\hline \multirow[t]{2}{*}{$\operatorname{lnMX}$} & $0.067 * * *$ & $0.059 * * *$ & $0.067 * * *$ & $0.055 * * *$ & 0.077 & 0.071 \\
\hline & $(0.000)$ & $(0.000)$ & $(0.000)$ & $(0.002)$ & $(0.000)$ & $(0.000)$ \\
\hline \multirow[t]{2}{*}{$\operatorname{lnES}$} & $-0.032 * * *$ & $-0.041 * * *$ & $-0.032 * * *$ & $-0.042 * * *$ & -0.043 & -0.059 \\
\hline & $(0.000)$ & $(0.000)$ & $(0.000)$ & $(0.000)$ & $(0.000)$ & $(0.000)$ \\
\hline \multirow[t]{2}{*}{$\operatorname{lnUR}$} & $-0.167 * * *$ & $-0.158 * * *$ & $-0.169 * * *$ & $-0.140 * * *$ & -0.165 & -0.150 \\
\hline & $(0.000)$ & $(0.000)$ & $(0.000)$ & $(0.001)$ & $(0.000)$ & $(0.000)$ \\
\hline \multirow[t]{2}{*}{ lnIER.FDI } & & & 0.003 & & & \\
\hline & & & $(0.462)$ & & & \\
\hline \multirow[t]{2}{*}{ lnEER.FDI } & & & & $-0.031 * * *$ & & \\
\hline & & & & $(0.025)$ & & \\
\hline \multirow[t]{2}{*}{ lnIER.TI } & & & & & $0.001 * * *$ & \\
\hline & & & & & $(0.003)$ & \\
\hline \multirow[t]{2}{*}{ lnEER.TI } & & & & & & -0.249 \\
\hline & & & & & & $(0.120)$ \\
\hline \multirow[t]{2}{*}{ Constant } & $0.748 * * *$ & $0.760 * * *$ & $0.747 * * *$ & $0.577 * * *$ & 0.888 & 0.921 \\
\hline & $(0.000)$ & $(0.000)$ & $(0.000)$ & $(0.000)$ & $(0.000)$ & $(0.000)$ \\
\hline \multirow[t]{2}{*}{ Sargan } & 24.785 & 25.729 & 23.839 & 25.407 & 24.406 & 26.483 \\
\hline & [1.000] & {$[1.000]$} & {$[1.000]$} & [1.000] & [1.000] & [1.000] \\
\hline Sample & 480 & 480 & 480 & 480 & 480 & 480 \\
\hline
\end{tabular}

Note: $* * * \mathrm{p}<0.01, * * \mathrm{p}<0.05, * \mathrm{p}<0.1$ 
to pollution-intensive industries is to be crowded out. However, the coefficient of interaction between investment-type regulation and foreign investment is negative without being significant. Considering that Chinese government subsidies in industrial pollution control investments are mainly given to stateowned enterprises, investment-type environmental regulations have limited impact on foreign-invested enterprises.

The elasticity coefficient is significantly positive for the interaction item of investment-type regulation and technological innovation, showing that raising the level of investment-type regulation advances regional innovation in technology and ultimately promotes green productivity. Compared with expenditure-type environmental regulation, investment-type regulation can form enterprises' fixed assets and generate income, often the choice made for sustainable development by those enterprises based on their long-term interests. For industrial pollution control in China, investment sources mainly include government budgeting, enterprise self-financing, and bank loans. Notably, government subsidies may share the pressure on enterprises for pollution control, reduce costs in environmentprotection investment, and play a guiding role in technological innovation. Therefore, investment-type regulation is beneficial to reducing enterprises' risk in technological innovation, enhancing their confidence and expectations while being more beneficial for the generation of incentives for enterprises' technological innovation over a long period of time.

The elasticity coefficient of the interaction between expenditure-type regulation and technological innovation is negative and not remarkable. This shows that expenditure-type regulation has not taken an active part in guiding technological innovation. One possible explanation is that although the expenditure of pollutant discharge fees in industrial enterprises will increase their production costs, the proportion of this expenditure to these enterprises' total cost is relatively low. Therefore, as a rational choice, manufacturers are more willing to pay pollution fees than to carry out technological innovation to become cleaner. Some manufacturers have even diverted funds originally earmarked for R \& D in order to pay pollution fees related to short-term financial goals. The crowding out brought by expenditure-type regulation reduces enterprises' investment in technological innovation (especially green innovation) and results in their failure to duly play an incentivizing role.

\section{Robustness Test}

To further verify the soundness of the above findings, we used spatial distance weights instead of the geographic distance weight matrix to check the effect of environmental regulations on green productivity as shown in this paper. From Table 8 , it is easy to see that regulation, whether investment-type or expenditure- type, has an obvious U-shaped relationship with green productivity.

These results reconfirm that expenditure-type regulation improves green productivity by influencing FDI, while investment-type environmental regulation improves green productivity by promoting technological innovation. In addition, the results emphasize that green productivity shows both significant path-dependent characteristics and spatial spillover effects, consistent with the paper's findings as a whole.

\section{Conclusions and Policy Recommendations}

\section{Conclusions}

This paper uses GML index to measure green productivity and analyzes the impact of different types of environmental regulations on green productivity by applying 30 provinces' samples from across China, 2001-2016. The main conclusions are as follows.

China's green productivity showed a trend of growth during the study period, but there were significant differences among regions, with stronger trend in the east and weaker in the middle and west. This green productivity has an obvious spatial spillover effect, which generally shows the characteristics of agglomeration distribution in China. This result indicates that, under technology diffusion, green productivity in each area is strongly associated with that in geographically adjacent areas.

Both investment-type regulation and expendituretype regulation have a U-shaped relationship with green productivity. It was implied that environmental regulation has a threshold effect on green productivity. Before the inflection point, environmental regulation would negatively influence green productivity; after the inflection point, raising the level of environmental regulation would effectively boost green productivity growth. According to the inflection point data value, investment- and expenditure-type regulation in most provinces of China stands in the left side of the $U$ curve, indicating that environmental regulation had a limited effect on green productivity growth during the study period.

Environmental regulation may boost green productivity through FDI and technological innovation, but the effect depends on the kind of regulation applied. Strict expenditure-type environmental regulation effectively raises the bar for foreign-investment entry, attracting more environment-friendly foreign investment and benefiting growth in green productivity; however, there is no positive interaction between investment-type environmental regulation and FDI. Additionally, investment-type regulation prompts regional growth in green productivity by promoting technological innovation. Unfortunately, due to crowding out on R \& D costs, expenditure-type environmental regulation has not been able to improve 
green productivity through technological innovation in this sample.

The study find that FDI has a positive impact regional green productivity, confirming the Porter hypothesis and denying the pollution heaven hypothesis. Furthermore, green productivity is positively associated with marketization and technological innovation, and increased urbanization, along with coal consumption, hinders the growth of green productivity.

\section{Policy Recommendations}

These research conclusions have important guiding significance for policymaking. First of all, it is important to strengthen environmental regulations in all regions of China. On one side, the country should make more substantial investments in environmental protection and management, constantly introducing advanced technology and equipment to reduce environmental pollution. On the other side, the administration should perfect the collection system and trading mechanism for pollution charges, and it should raise the level of expenditure-type regulation. In short, to realize a win-win situation of economy and environment by enhancing the level of environmental regulation, it is essential to cross the inflection point of the U-shaped curve demonstrated in this paper.

Secondly, although the influx of FDI has promoted the growth of green productivity in China, there is still much room for improvement. The country should put an end to low-quality FDI, and avoid becoming a "pollution paradise," by increasing the intensity of its regulations. There is a need to adjust the strategy for attracting foreign indirect investment, and to enhance the positive spillover effect of green-technology FDI. Foremost of these considerations is that the government should coordinate its policies for attracting foreign investment in various regions, and it should prevent vicious competition in the process of attracting overseas investments. The administrative department should selectively introduce high-quality FDI, guide it into high-tech industry, and improve the technology spillover effect [52]. In addition, local governments should also create good market system environments, encourage foreign-owned companies to implement green-technology innovations, and promote technology diffusion and spillover.

Lastly, considering that environmental regulation not only incentivizes technological innovation but also risks squeezing research expenses, it is required that the Chinese government enrich its regulation tools and improve efficiency. The government should comprehensively apply multiple tools - such as emissions trading, abatement subsidies, environment taxation, etc. - to enhance the incentive effect of regulation and reduce regulation cost. Furthermore, it is imperative to take incentive measures, such as tax preferences, to guide polluting enterprises toward realizing clean production and to encourage the application of green technology.

\section{Outlook}

This study explores the impact mechanism of environmental regulation on green productivity, which is significant to green development in theory and practice for China. However, there is still more space for discussion on this topic. In view of the significant regional differences in China, it is valuable to explore the temporal and spatial differences in the environmental regulation effect on green productivity. Due to the complexity of the influence mechanism of environmental regulation, it is worth trying to examine the environmental regulation effect on green productivity by promoting industrial upgrading, impelling pollution transfer and adjusting energy structure. In addition, this research examines the environmental regulation impact from the provincial scale due to limited data availability. In the future, it also investigation the impact from the scale data of prefecture-level cities.

\section{Acknowledgements}

This research was funded by Youth Foundation of Shanxi University of Finance and Economics [Grant No. QN-2019012], the research project of philosophy and Social Sciences in Colleges and universities in Shanxi Province[Grant No. 2019W093], the planning of philosophy and Social Sciences in Shanxi Province[Grant No. 2019B149], and Humanity and Social Science Youth foundation of Ministry of Education of China[Grant No. 20YJCZH068].

\section{Conflict of Interest}

The authors declare no conflict of interest.

\section{References}

1. LIN B., TAN R. Ecological total-factor energy efficiency of China's energy intensive industries [J]. Ecological Indicators, 70, 480, 2016.

2. DONG F., LI J., LI K., SUN Z., ZHANG S. Causal chain of haze decoupling efforts and its action mechanism: Evidence from 30 provinces in China [J]. Journal of Cleaner Production, 245, 118889, 2020.

3. DONG F., ZHANG S.N., LONG R.Y., ZHANG X.Y., SUN Z.Y. Determinants of haze pollution: An analysis from the perspective of spatiotemporal heterogeneity [J]. Journal of Cleaner Production, 222, 768, 2019.

4. LU Y., ZHANG Y., CAO X., WANG C., ZHANG Z. Forty years of reform and opening up: China's progress toward a sustainable path[J]. Science Advances, 5, 9413, 2019.

5. Dong F., YU B., PAN Y. Examining the synergistic effect of $\mathrm{CO}_{2}$ emissions on $\mathrm{PM}_{25}$ emissions reduction: Evidence 
from China [J]. Journal of Cleaner Production, 223, 759, 2019.

6. DONG F., LI J., WANG Y., ZHANG X.Y., ZHANG S.N., ZHANG S.Q. Drivers of the decoupling indicator between the economic growth and energy-related $\mathrm{CO}_{2}$ in China: A revisit from the perspectives of decomposition and spatiotemporal heterogeneity $[\mathrm{J}]$. Science of the Total Environment, 685, 631, 2019.

7. LI K., LIN B. Economic growth model, structural transformation, and green productivity in China[J]. Applied Energy, 187, 489, 2017.

8. CHEN S., GOLLEY J. 'Green' productivity growth in China's industrial economy [J]. Energy Economics, 44, 89, 2014.

9. PENG X. Strategic interaction of environmental regulation and green productivity growth in China: Green innovation or pollution refuge? [J]. Science of The Total Environment, 732, 139200, 2020.

10. GREENSTONE M., LIST JA., SYVERSON C. The effects of environmental regulation on the competitiveness of US manufacturing. National Bureau of Economic Research, 2012.

11. LI B., WU S. Effects of local and civil environmental regulation on green total factor productivity in China: A spatial Durbin econometric analysis [J]. Journal of Cleaner Production, 153, 342, 2017.

12. WANG Y., SHEN N. Environmental regulation and environmental productivity: The case of China [J]. Renewable and Sustainable Energy Reviews, 62, 758, 2016.

13. ZHANG Y., JIN P., FENG D. Does civil environmental protection force the growth of China's industrial green productivity? Evidence from the perspective of rentseeking $[\mathrm{J}]$. Ecological Indicators, 51, 215, 2015.

14. ALBRIZIO S., KOZLUK T., ZIPPERER V. Environmental policies and productivity growth: Evidence across industries and firms [J]. Journal of Environmental Economics and Management, 81, 209, 2017.

15. HANCEVIC P.I. Environmental regulation and productivity: The case of electricity generation under the CAAA-1990 [J]. Energy Economics, 60, 131, 2016.

16. XIE R.H., YUAN Y.J., HUANG J.J. Different types of environmental regulations and heterogeneous influence on "green" productivity: Evidence from China[J]. Ecological Economics, 132, 104, 2017.

17. ARIMURA T.H., HIBIKI A., KATAYAMA H. Is a voluntary approach an effective environmental policy instrument? A case for environmental management systems [J]. Journal of Environmental Economics and Management, 55 (3), 281, 2008.

18. ZHAO X., YIN H., ZHAO Y. Impact of environmental regulations on the efficiency and $\mathrm{CO}_{2}$ emissions of power plants in China[J]. Applied Energy, 149, 238, 2015.

19. ZHANG J.X., CAI N., YANG C. Impact of environmental regulations on China's industrial green growth index $[\mathrm{J}]$. Chinese Journal of Population, Resources and Environment, 25, 24, 2015 [In Chinese].

20. REN S., LI X., YUAN B., LI D., CHEN X. The effects of three types of environmental regulation on eco-efficiency: A cross-region analysis in China [J]. Journal of Cleaner Production, 173, 245, 2018.

21. JIANG X.Z., NING C., JIAN U.M., YANG C. Independent innovation, technology introduction and green growth of industry in China: An empirical research based on industry heterogeneity $[\mathrm{J}]$. Studies in Science of Science, 33, 185, 2015 [In Chinese].
22. LING G.L., QU Y., TSENG M.L. The interaction effects of environmental regulation and technological innovation on regional green growth performance [J]. Journal of Cleaner Production, 162, 894, 2017.

23. CHEN C., LAN Q., GAO M., SUN Y.W. Green total factor productivity growth and its determinants in China's industrial economy [J]. Sustainability, 10, 1052, 2018

24. PORTER M.E., LINDE C.V.D. Toward a new conception of the environment-competitiveness relationship [J]. Journal of Economic Perspectives, 9, 97, 1995.

25. LANJOUW J.O., MODY A. Innovation and the international diffusion of environmentally responsive technology[J]. Research Policy, 25(4), 549, 1996.

26. LANOIE P., LAURENT-LUCCHETTI J., JOHNSTONE N., AMBEC S. Environmental policy, innovation and performance: New insights on the Porter hypothesis [J]. Journal of Economics \& Management Strategy, 20 (3), 803, 2011.

27. RUBASHKINA Y., GALEOTTI M., VERDOLINI E. Environmental regulation and competitiveness: Empirical evidence on the Porter Hypothesis from European manufacturing sectors [J]. Energy Policy, 83, 288, 2015.

28. KOKKO A., ZEJAN M., TANSINI R. Trade regimes and spillover effects of FDI: Evidence from Uruguay [J]. Review of World Economics, 137, 124, 2001.

29. JUDE C. Technology spillovers from FDI. Evidence on the intensity of different spillover channels $[\mathrm{J}]$. The World Economy, 39 (12), 1947, 2016.

30. MIELNIK O., GOLDEMBERG J. Foreign direct investment and decoupling between energy and gross domestic product in developing countries [J]. Energy Policy, 30 (2), 87, 2002.

31. KIM M. Productivity spillovers from FDI and the role of domestic firm's absorptive capacity in South Korean manufacturing industries [J]. Empirical Economics, 48 (2), 807, 2015.

32. TIWARI A.K., MUHAMMAD S. The environmental Kuzents Curve and the role of coal consumption in India: Cointegration and causality analysis in an open economy [J]. Renewable and Sustainable Energy Reviews, 18, 519, 2013.

33. LEE J.W. The contribution of foreign direct investment to clean energy use, carbon emissions and economic growth [J]. Energy Policy, 55, 483, 2013.

34. TAO F., ZHANG H., HU J., XIA X.H. Dynamics of green productivity growth for major Chinese urban agglomerations [J]. Applied Energy, 196, 170, 2017.

35. YUAN B., XIANG Q. Environmental regulation, industrial innovation and green development of Chinese manufacturing: Based on an extended CDM model [J]. Journal of Cleaner Production, 176, 895, 2018.

36. CAO X., WANG P., ZHU B. Has foreign direct investment increased air pollution in China? A hierarchical linear model approach[J]. Natural Hazards, 91 (2), 659, 2018.

37. FENG Z., CHEN W. Environmental regulation, green innovation, and industrial green development: An empirical analysis based on the Spatial Durbin model [J]. Sustainability, 10, 223, 2018.

38. ZHANG J., FU X. FDI and environmental regulations in China [J]. Journal of the Asia Pacific Economy, 13 (3), 332, 2008.

39. HAO Y., DENG Y., LU Z.N., CHEN H. Is environmental regulation effective in China? Evidence from city-level panel data $[\mathrm{J}]$. Journal of Cleaner Production, 188, 966, 2018. 
40. MULATU., ABAY. The Structure of UK Outbound FDI and Environmental Regulation [J]. Environmental and Resource Economics, 68 (1), 65, 2017.

41. CHUNG S. Environmental regulation and foreign direct investment: Evidence from South Korea [J]. Journal of Development Economics, 108, 222, 2014.

42. POPP D., NEWELL R.G., JAFFE A.B. Energy, the environment, and technological change $[\mathrm{M}]$ Handbook of the Economics of Innovation. North-Holland, 2, 873, 2010.

43. OH D. A global Malmquist-Luenberger productivity index [J]. Journal of Productivity Analysis, 34, 183, 2010.

44. BÖCHER M. A theoretical framework for explaining the choice of instruments in environmental policy [J]. Forest Policy and Economics, 16, 14, 2012.

45. BÖHRINGER C., MOSLENER U., OBERNDORFER U., ZIEGLER A. Clean and productive? Empirical evidence from the German manufacturing industry $[\mathrm{J}]$. Research Policy, 41 (2), 442, 2012.

46. HOU Y., CHEN H.Y. Optimal Sewage Charges of A Three-stage Game for the Government, Polluting Firms and the Environment Firms [J]. Nankai Economic Studies, 1, 121, 2013 [In Chinese].

47. LI R., RAMANATHAN R. Exploring the relationships between different types of environmental regulations and environmental performance: Evidence from China $[\mathrm{J}]$. Journal of Cleaner Production, 196, 1329, 2018.

48. COSTANTINI V., CRESPI F., MARIN G., PAGLIALUNGA E. Eco-innovation, sustainable supply chains and environmental performance in European industries [J]. Journal of Cleaner Production, 155, 141, 2017.

49. GHISETTI C., QUATRARO F. Green technologies and environmental productivity: A cross-sectoral analysis of direct and indirect effects in Italian regions[J]. Ecological Economics, 132, 1,2017.

50. COSTANTINI V., MAZZANTI M., MONTINI A. Environmental performance, innovation and spillovers. Evidence from a regional NAMEA [J]. Ecological Economics, 89, 101, 2013.

51. YUAN Y.J., XIE R.H. FDI, Environmental Regulation and China's Industrial Green Total Factor Productivity Growth - An Empirical Study based on Luenberger Index [J]. International Trade Issues, 08, 84, 2015 [In Chinese].

52. DONG F., WANG Y., ZHENG L., LI J., XIE S. Can industrial agglomeration promote pollution agglomeration? Evidence from China[J]. Journal of Cleaner Production, 246, 118960, 2019. 